\title{
Modulation of Skeletal Muscle Sodium Channels in a Satellite Cell Line by Protein Kinase C
}

\author{
Randal Numann, ${ }^{1}$ Stephen D. Hauschka, ${ }^{2}$ William A. Catterall, ${ }^{1}$ and Todd Scheuer ${ }^{1}$ \\ Departments of 'Pharmacology and 'Biochemistry, University of Washington, Seattle, Washington 98195
}

Adult vertebrate skeletal muscle sodium channels are responsible for the spread of excitation from the end-plate through the muscle membrane and transverse tubular system that ultimately leads to contraction. These channels can be distinguished from other sodium channels by their sensitivity to both $\mu$-conotoxin and TTX. The mouse satellite muscle cell line MM14 expresses only TTX- and $\mu$-conotoxin-sensitive sodium channels having the physiological characteristics of adult skeletal muscle channels in both undifferentiated myoblasts and differentiated myotubes. Using undifferentiated and differentiated MM14 cells as well as primary cultures of rat skeletal muscle, we have examined modulation of adult skeletal muscle sodium channels by activators of protein kinase $C$ (PKC). Stimulation of PKC by 1-oleoyl-2-acetyl-sn-glycerol (OAG) slows sodium current macroscopic inactivation rate by up to $70 \%$ and reduces the peak sodium current as much as $88 \%$. Single-channel analysis reveals prolonged single channel openings and greatly increased probability of multiple channel openings during sustained depolarizations. These effects are due to PKC activation since they are blocked by a specific peptide inhibitor of PKC. The two effects of OAG are sequential. Low OAG concentrations can cause slowed macroscopic sodium current inactivation in the absence of peak current reduction, and intermediate concentrations of OAG cause slowing of inactivation followed by reduction of peak current. The separation of these two effects indicates that PKC modulation of the skeletal muscle sodium channel may occur by phosphorylation at two independent sites. PKC modulation of muscle sodium channels is expected to have important effects on muscle excitability and resultant contractile activity. Detection of adult skeletal muscle ion channels in replicating MM14 cells suggests that satellite cells may express a distinct subset of muscle-specific genes prior to activation of the terminal differentiation program.

[Key words: sodium channel, phosphorylation, protein kinase $C$, skeletal muscle, development, satellite cells, mouse, rat]

Vertebrate skeletal muscle relies on voltage-sensitive sodium channels for the active spread of excitation from a single endplate throughout the surface membrane and into the transverse tubules in order to activate contraction. Sodium currents in

Received Feb. 15, 1993; revised Nov. 30, 1993; accepted Dec. 31, 1993.

We thank Ms. DeeAnn Gregory for assistance with MMl4 cell culture, Dr. A. Scuptoreanu for preparation of skeletal muscle myoballs, and Dr. R. Westenbroek for photographic assistance. This work was supported by Research Grant NS15751 from NIH and a grant from the Muscular Dystrophy Association to W.A.C. and AR 18860 from NIH to S.D.H.

Correspondence should be addressed to Dr. Todd Scheuer, Department of Pharmacology, SJ30, University of Washington, Seattle, WA 98195.

Copyright (C) 1994 Society for Neuroscience $0270-6474 / 94 / 144226-11 \$ 05.00 / 0$ adult mammalian skeletal muscle are TTX sensitive $\left(K_{D}=5-\right.$ 10 nм; Ritchie and Rogart, 1977; Pappone, 1980) and can be distinguished from other TTX-sensitive sodium currents because they are preferentially blocked by $\mu$-conotoxin (Minoshima et al., 1984; Cruz et al., 1985; Gonoi et al., 1987). The channel protein responsible for the sodium current has been purified and consists of an $\alpha$ subunit of $260 \mathrm{kDa}$ and a $\beta$ subunit of $30 \mathrm{kDa}$ (for review, see Barchi, 1988). cDNA encoding the $\alpha$ subunit (termed $\mu 1$ or skM1) has recently been cloned, sequenced, and expressed in Xenopus oocytes (Trimmer et al., 1989) and mammalian cells (Ukomadu et al., 1992). Like the native channel, expressed channels are highly TTX-and $\mu$-conotoxin-sensitive.

Modulation of sodium channel activity by protein phosphorylation would alter the rate and efficacy of electrical excitation in response to neuronal stimulation and would have important effects on muscle function. Arachidonic acid and related fatty acids that can activate protein kinase $C$ (PKC) reduce sodium currents in neuroblastoma cells (Linden and Routtenberg, 1989), and activation of PKC with phorbol esters reduces sodium currents in Xenopus oocytes injected with rat brain polyA mRNA (Sigel and Baur, 1988). Sodium current reduction by activation of $\mathrm{PKC}$ is associated with slowed macroscopic inactivation in rat brain neurons and in cloned rat brain type IIA sodium channels expressed in Chinese hamster ovary cells (Numann et al., 1991) and in Xenopus oocytes (Schreibmayer et al., 1991). Modulation by PKC stimulation was blocked by mutation of the phosphorylated serine (Ser 1506) in a single PKC phosphorylation site to an alanine in the rat brain type IIA sodium channel $\alpha$ subunit (West et al., 1991). The consensus sequence for PKC phosphorylation at Ser 1506 is conserved in the $\mu 1$ sodium channel sequence (Trimmer et al., 1989). Conservation of this phosphorylation site suggested that the skeletal muscle sodium channel might also be modulated by PKC. In these experiments, we have examined the modulation of skeletal muscle sodium channels by activation of PKC in a satellite cell line derived from an adult mouse (MM14; Linkhart et al., 1981) and in primary cultures of rat skeletal muscle cells.

A preliminary report of these results has appeared in abstract form (Numann et al., 1992a).

\section{Materials and Methods}

Cell culture. MM14 cells were derived by serial subcloning of myoblasts from the leg muscle of a 60 -d-old male BALB/c mouse (Linkhart et al., 1981). Expanded cells used in the present study are a near-tetraploid clonal derivative (MM14DZ1A) that has been used routinely for the past 10 years. A complete description of the differentiation behavior of these vells is provided in Clcgg ct al. (1987). Cells were plated on gelatincoated $35 \mathrm{~mm}$ culture dishes at a density of $3000 \mathrm{cells} /$ dish in Ham's F10 (GIBCO) supplemented with $0.8 \mathrm{~mm} \mathrm{CaCl}_{2}, 15 \%$ pretested horse serum, and $2 \mathrm{ng} / \mathrm{ml}$ human basic recombinant fibroblast growth factor (courtesy of Dr. Steve McKnight, Zymogenetics Corp., Seattle). Cells used for individual experiments were cultivated from frozen stocks of 
MM14DZIA. Myoblast cultures were grown exponentially for $1-2 \mathrm{~d}$ with FGF additions of $2 \mathrm{ng} / \mathrm{ml}$ at $12 \mathrm{hr}$ intervals. Electrical recordings from myoblasts were made $1-2 \mathrm{~d}$ after plating. To induce differentiation FGF additions were discontinued and cells began to differentiate and form myotubes within 1-2 d. The appearance of fused myotubes (see Fig. $1 B$ ) was used as a marker when recording from differentiated cells. Muscle differentiation was also assessed by immunostaining fixed cultures for myosin heavy chain as described in Clegg et al. (1987). Rat skeletal muscle myoblasts were prepared from $20 \mathrm{~d}$ rat embryos as described previously (Lawrence et al., 1981) and cultured in 10\% horse serum (Hazleton), 5\% fetal calf serum (Hyclone), and 85\% Dulbecco's modified Eagle's medium (GIBCO). After $5 \mathrm{~d}, 10 \mu \mathrm{M}$ colchicine was added to form myoballs, which remained suitable for electrical recording for up to 3 weeks.

Electrophysiology. Whole-cell and cell-attached patch-clamp recordings were made using standard techniques (Hamill et al., 1981). Pipettes for patch-clamp recording were formed from capillary micropipettes (VWR) that were coated with Sylgard and fire-polished prior to use. For single-channel recordings, pipettes formed from Corning 7052 glass were used. Membrane currents were recorded with an Axopatch $1 \mathrm{C}$ patchclamp amplifier (Axon Instruments) using the $500 \mathrm{M} \Omega$ resistor for wholecell recording and the $50 \mathrm{G} \Omega$ resistor for cell-attached recording. Voltage pulses were generated and data were recorded and analyzed using a personal computer-based data acquisition system (Indec Systems). Unless otherwise indicated, currents were filtered at $5 \mathrm{kHz}$ using an 8-pole Bessel filter (Frequency Devices) and digitized at $40 \mathrm{kHz}$. Linear leakage and capacitance were corrected by subtraction of traces with no channel activity or scaled pulses recorded in voltage ranges where channel activity was absent. Current traces used for leakage subtraction were sometimes fit with a series of exponentials, and the resulting fit trace was used for subtraction to avoid adding noise to the records. The macroscopic current records shown are generally that average of 5-20 individual current traces.

For whole-cell recordings, the bath solution (solution $\mathrm{A}$ ) contained (in $\mathrm{mM}$ ) $140 \mathrm{NaCl}, 5 \mathrm{KCl}, 1.5 \mathrm{CaCl}_{2}, 2 \mathrm{MgCl}_{2}, 5 \mathrm{HEPES}$, and 5 glucose. The pipette solution (solution B) contained $120 \mathrm{CsF}, 20 \mathrm{CsCl}, 10 \mathrm{NaCl}$, 5 CsEGTA, and 5 HEPES. For cell-attached experiments on undifferentiated MM14 myoblasts the bath solution (solution C) contained 140 $\mathrm{KCl}, 10 \mathrm{NaCl}, 0.5 \mathrm{CaCl}_{2}, 3 \mathrm{MgCl}_{2}$, and $5 \mathrm{HEPES}$, and the pipette solution (solution D) contained $150 \mathrm{NaCl}, 1.5 \mathrm{CaCl}_{2}, 2.0 \mathrm{MgCl}_{2}$, and 5 HEPES. For experiments where peptide kinase inhibitors were injected, the bath solution (solution E) contained $10 \mathrm{NaCl}, 50 \mathrm{KCl}, 90$ $\mathrm{K}$-aspartate, $3 \mathrm{MgCl}_{2}$, and $5 \mathrm{HEPES}$ to improve survival. For cellattached experiments on differentiated MM14 cells and on skeletal muscle myoballs, extracellular solutions with reduced $\mathrm{CaCl}_{2}$ were used to minimize interference from calcium currents. The bath solution (solution $\mathrm{F}$ ) contained $150 \mathrm{KCl}, 4 \mathrm{MgCl}_{2}, 0.01 \mathrm{CaCl}_{2}$ (EGTA-buffered), and $5 \mathrm{HEPES}$, and the pipette solution (solution $\mathrm{G}$ ) contained $150 \mathrm{NaCl}$, $0.05 \mathrm{CaCl}_{2}, 4 \mathrm{MgCl}_{2}$, and 5 HEPES. All solutions were $\mathrm{pH} 7.4$, and experiments were performed at room temperature (approximately $22^{\circ} \mathrm{C}$ ).

1-Oleoyl-2-acetyl-sn-glycerol (OAG) (Sigma) was maintained as a 8.3 mM stock in dimethyl sulfoxide (DMSO). Phorbol ester ( $\beta$-phorbol 12myristate 13-acetate) (PMA) (Calbiochem) was maintained as a $10 \mathrm{mM}$ stock in DMSO. Tetrodotoxin (1 $\mathrm{mm}$; Calbiochem) and $\mu$-conotoxin GIIIA ( $100 \mu \mathrm{M}$; Sigma) were maintained as frozen aqueous stocks. Toxins were diluted with bath solution (5-100-fold) prior to addition to the recording chamber. Bovine serum albumin (3-5\%) was sometimes added to this final mixture to avoid toxin adhesion to plasticware, but this addition did not seem to alter toxin efficacy. After toxin addition, the recording chamber was mixed by repeated aspiration and readdition of small volumes to ensure uniform concentration. The PKC pseudosubstrate inhibitor peptide was a kind gift of Drs. K. Meier and E. G. Krebs. The peptide inhibitor of cAMP-dependent protein kinase was CAMPdependent protein kinase inhibitor PKI 1-24 (Peninsula Labs). Peptides were diluted in $140 \mathrm{mM} \mathrm{KCl}$ prior to microinjection. Peptides were microinjected using pipettes formed from sterilized fiber-filled capillary glass (World Precision Instruments). Oral pressure was applied until cell appearance changed slightly. The volume injected was estimated to be less than $1 / 10$ the cell volume.

\section{Results}

Characterization of sodium channels in MM14 cells

MM14 cells maintain an undifferentiated phenotype and proliferate when grown in the presence of serum and FGF, but differentiate and express a muscle-specific phenotype when the growth factor is removed (Clegg et al., 1987). While MM1 4 cells have becn used extensively to study muscle differentiation, they have never been characterized electrophysiologically. Figure $1 A$ shows a photograph of MM14 satellite cells cultured in the presence of FGF to maintain an undifferentiated phenotype as evidenced by the lack of staining for myosin heavy chain (MHC). Undifferentiated MM14 cells are spherical to slightly elongate (20-25 $\mu \mathrm{m}$ diameter) with a whole-cell capacitance of $33.2 \pm$ $9.2 \mathrm{pF}(n=11)$. Figure $1 B$ shows cells 24 hr after switching cultures to FGF-free growth medium. At this time, some cells remain round but have begun to differentiate and are $\mathrm{MHC}$ positive. Other MHC-positive cells have elongated and begun to form multinucleate myotubes. By $48 \mathrm{hr}$, most cells will have formed myotubes and be fully differentiated (not shown). Within 6-8 hr of FGF removal MM14 cells express many musclespecific proteins including muscle-specific creatine kinase, $\mathrm{ACh}$ receptor, $\alpha$-actin, and myosin heavy chain (Linkhart et al., 1980, 1981; Bulinski et al., 1983; Clegg et al., 1987).

Whole-cell voltage-clamp recordings from undifferentiated MM14 cells reveal the presence of a large, rapidly activating and inactivating inward current (Fig. $2 A$ ) that was more than $95 \%$ blocked by $200-400$ nм TTX $(n=12)$. The complete inhibition by a low concentration of TTX suggested that the current was carried by TTX-sensitive sodium channels, rather than by the TTX-resistant isoform with $K_{d}=2 \mu \mathrm{M}$ that predominates in adult cardiac muscle (Baer et al., 1976; Cohen et al., 1981) and that appears in skeletal muscle after denervation (Ritchie and Rogart, 1977; Pappone, 1980), or by a completely TTX-insensitive embryonic sodium channel isoform (Sculptoreanu et al., 1992). Adult skeletal muscle sodium channels can be differentiated from other TTX-sensitive sodium channels because they are preferentially blocked by $\mu$-conotoxin (Cruz et al., 1985; Gonoi et al., 1987). Figure $2 B$ shows currents recorded from an undifferentiated MM14 cell before and during application of synthetic $\mu$-conotoxin (500 nM). Peak currents recorded from a population of cells were reduced by $92 \%$ in the presence of 500 nM $\mu$-conotoxin compared to control (control: mean $=$ $5.78 \pm 2.27 \mathrm{nA}, n=15 ; \mu$-conotoxin: mean $=0.41 \pm 0.12 \mathrm{nA}$, $n=12$ ). Thus, the sodium current in these cells has the pharmacologic profile of the adult skeletal muscle sodium channel. Block of inward current in MM14 cells was sometimes incomplete at high toxin concentrations. The unblocked current $(<5 \%$ for TTX, $<8 \%$ for $\mu$-conotoxin) had a time course and voltage dependence similar to the toxin-sensitive current. Since it was absent when cells were detached from the bottom of the dish, it was probably due to poor access of the blocking toxins to the attached portion of the cell.

Skeletal muscle sodium channels have a relatively negative voltage dependence of activation and inactivation (Adrian and Marshall, 1977; Pappone, 1980; Gonoi et al., 1985; Mathes et al., 1991). Sodium currents in MM14 cells had kinetics typical of muscle sodium channels (Fig. $3 A$ ). They were activated during voltage-clamp steps positive to $-60 \mathrm{mV}$, peak currents were observed near $-30 \mathrm{mV}$, and currents reversed near $+70 \mathrm{mV}$ (Fig. $3 B ; n=8$ ). Conductance, $G$, was calculated as

$$
G=I\left(V-V_{\mathrm{rev}}\right)
$$

where $I$ was the measured current, $V$ is the voltage, and $V_{\mathrm{rev}}$ is the measured reversal potential.

Conductance-voltage plots were fit with a Boltzmann distribution, 

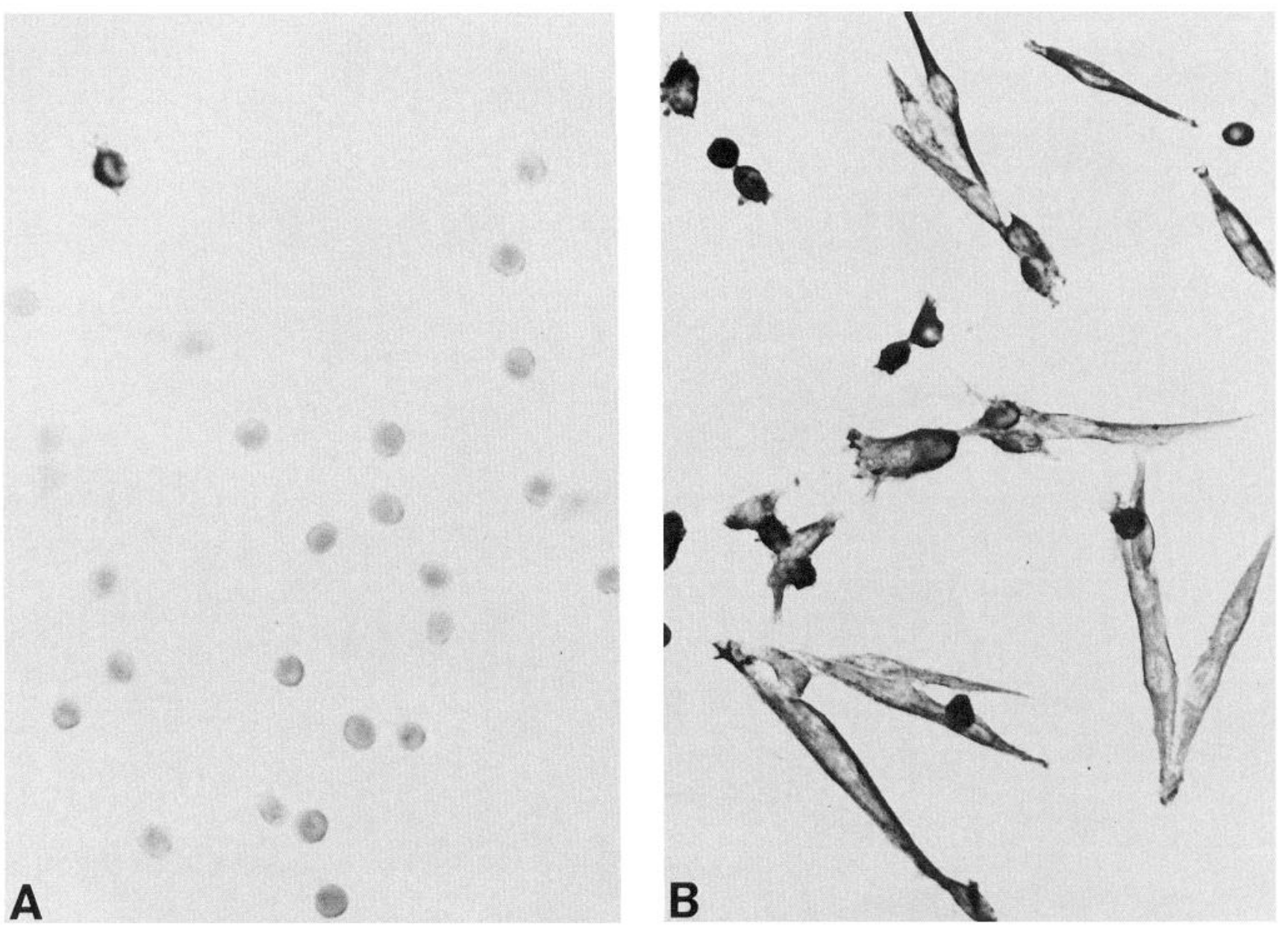

Figure 1. Undifferentiated and differentiated MM14 cells. A, MM14 cells after $1 \mathrm{~d}$ of culture in FGF-containing medium. B, MM14 cells 24 hr after switching to medium without FGF. Cells were stained with hematoxylin and immunostained with MF20 to detect myosin heavy chain (MHC). Replicating myoblast cultures such as that shown in $A$ exhibit less than $1 \%$ MHC-positive cells. The field shown in $A$ was chosen to include one such rare cell (dark cell in upper left corner) to demonstrate the presence of MF20. More than $95 \%$ of differentiated cells such as those shown in $B$ were MHC positive. Magnification, $343 \times$.

$$
G=1 /\left(1+\exp \left(\left(V-V_{0.5}\right) / k\right)\right)
$$

where $V_{0.5}$ is the half-activation voltage and $k$ is a slope factor. Fits of activation curves gave a $V_{0.5}=-45.2 \pm 5.8 \mathrm{mV}$ and $k$ $=-5.9 \pm 1.0 \mathrm{mV}(n=15)$ (Fig. 3C). Similar fits of steadystate inactivation curves gave $V_{0.5}=-91.3 \pm 2.7 \mathrm{mV}$ and $k=$ $6.3 \pm 0.72 \mathrm{mV}$ (Fig. $3 C$ ). This value can be compared to halfactivation values for mammalian muscle that range from -31 to $-52 \mathrm{mV}$ and half-inactivation voltages that range from -70 to $-92 \mathrm{mV}$ (Adrian and Marshall, 1977; Pappone, 1980; Gonoi et al., 1985; Mathes et al., 1991). These characteristics are consistent with expression of adult skeletal muscle $\mu 1$ sodium channels in MM14 cells.

\section{Modulation of skeletal muscle sodium channels in satellite cell myoblasts by $P K C$}

The diacylglycerol analog OAG was used to activate PKC and examine its effect on sodium channels in undifferentiated MM14 cells. Experiments were performed using cell-attached patches to maintain an intact cell membrane and avoid dialysis of intracellular constituents. Such patches often contained multiple channels and macroscopic currents were readily recorded (Fig.
4). Seconds after adding $60 \mu \mathrm{M}$ OAG to the bath, the time course of macroscopic sodium current inactivation was slowed and peak current was reduced (Fig. 4). Concentrations of OAG between 20 and $60 \mu \mathrm{M}$ gave similar effects in seven other cells. Qualitatively similar effects were seen with $0.5 \mu \mathrm{M}$ of another activator of PKC, the phorbol ester PMA (data not shown).

The effects of OAG occurred at all potentials and were not associated with a significant shift $(<5 \mathrm{mV})$ in the voltage dependence of sodium current activation $(n=4)$ (Fig. $5 A, B)$. Sodium currents recorded at each test potential were reduced by OAG treatment and their decay was slowed (Fig. $5 A$ ). Currentvoltage relationships derived from a similar experiment showed no change in voltage dependence (Fig. $5 B$ ). Similarly, no change in the voltage dependence of sodium current inactivation was observed $(n=3)$ (Fig. $5 C$ ).

In the cell-attached recording mode, both the voltage dependence of activation as well as the reversal potential of the current were more negative than in the whole cell mode. In the cellattached mode, the actual potential experienced by the channel reflects the applied potential plus the resting potential of the cell. Although our solutions were designed to depolarize the cell to near $0 \mathrm{mV}$, the negative shift in the voltage-dependent pa- 
A

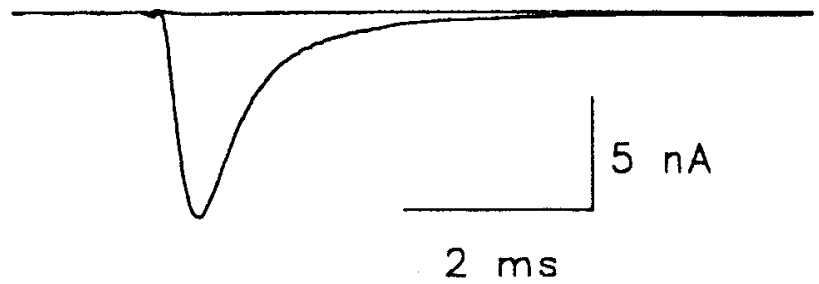

$B$

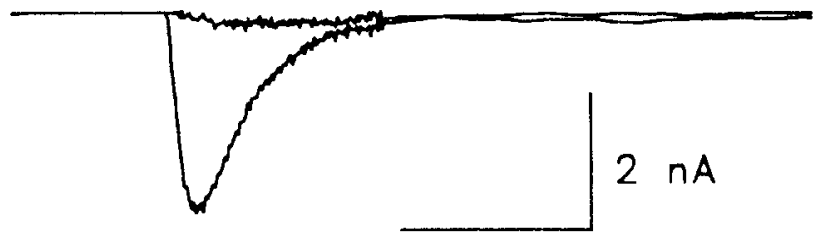

$2 \mathrm{~ms}$

Figure 2. Block of undifferentiated MM14 cell inward current by TTX and $\mu$-conotoxin. Shown are inward currents elicited by whole-cell voltage-clamp steps to $-30 \mathrm{mV}$ from a holding potential of $-111 \mathrm{mV}$ in the absence and presence of toxin: $A, 400 \mathrm{nм}$ TTX; $B, 500$ пм, $\mu$-conotoxin. Bath solution A, pipette solution B.

rameters is more consistent with the true resting membrane potential of the cell being depolarized to +10 to $+20 \mathrm{mV}$.

To test whether OAG effects were indeed due to activation of PKC, we used a specific pseudosubstrate peptide inhibitor of PKC (PKCI) having $K_{I}=150 \mathrm{~nm}$ (House and Kemp, 1987). MM 4 cells were microinjected with a solution containing 500 $\mu \mathrm{M}$ PKCI and cell-attached patch recordings were obtained within $20 \mathrm{~min}$. Application of OAG at high concentration $(>100$ $\mu \mathrm{M})$ to PKCI-injected cells had no effect on macroscopic sodium currents recorded in these patches (Fig. $6 A ; n=3$ ). The possibility that this block of the $\mathrm{OAG}$ effect was due to the injection procedure itself was controlled for by similar injection of a peptide inhibitor of cAMP-dependent protein kinase, PKAI (Cheng et al., 1986). Cells preinjected with PKAI responded normally to OAG (Fig. $6 B ; n=2$ ). These results confirm that the slowing of sodium current inactivation kinetics and reduction of peak current are indeed mediated by activation of PKC and are not due to activation of $\mathrm{c} \triangle \mathrm{MP}$-dependent protein kinase or to any PKC-independent effects of the DMSO vehicle.

\section{Modulation of skeletal muscle sodium channels in satellite cell} myotubes by $P K C$

Differentiated MM14 cell myotubes had large inward currents in cell-attached patches with voltage-dependent properties similar to the inward currents in undifferentiated myoblasts (Fig. 7). These currents were absent when $1 \mu \mathrm{M}$ TTX was included in the pipette $(n=12)$ and were evidently due to the same sodium channels present in the undifferentiated cells. They were also similarly affected by OAG (Fig. $7 A$ ). Macroscopic inactivation was slowed and peak current was reduced, but the concentration of $\mathrm{OAG}$ needed to produce these modulatory effects

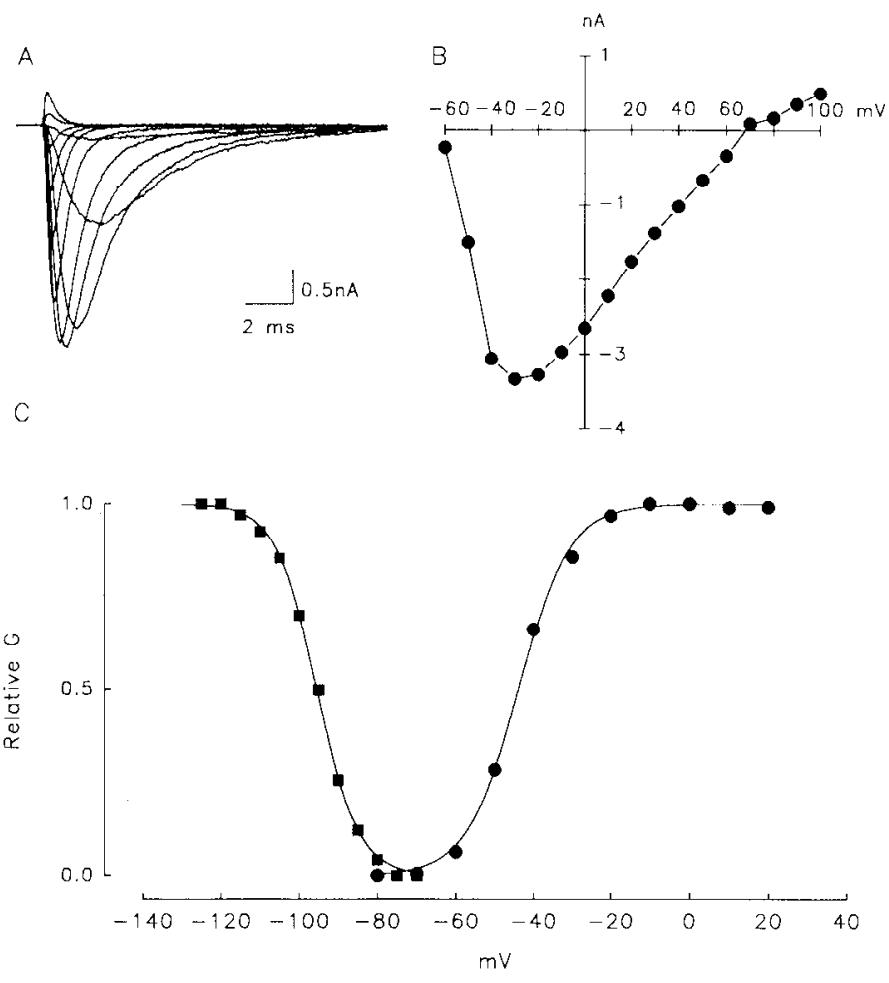

Figure 3. Voltage-dependent properties of sodium currents in undifferentiated MM 14 cells. $A$, Family of whole-cell sodium currents elicited by depolarizations to test pulse voltages from -60 to $-20 \mathrm{mV}$ in 10 $\mathrm{mV}$ steps and from 0 to $+100 \mathrm{mV}$ in $20 \mathrm{mV}$ steps. $B$, Peak inward current versus voltage relationship for the family of sodium currents in A. C, Activation (-) and inactivation ( $\mathbf{0}$ ) curves. Activation curve was determined from peak currents measured in $B$ as described in the text. The inactivation curve was determined by applying 125 -msec-long prepulse depolarizations followed by a test pulse to $-10 \mathrm{mV}$ from a holding potential of $-130 \mathrm{mV}$. The smooth curves through the points represent least-squares fits of Equation 2 to the data. For activation $V_{0.5}=43.8$ and $k=-6.6$. For inactivation $V_{0.5}=-95.4$ and $k=5.3$. Bath solution $\mathrm{A}$, pipette solution $\mathrm{B}$.

was two to three times higher than for undifferentiated cells (Table 1). As in undifferentiated cells, effects of OAG occurred without significant shifts in steady-state activation or inactivation $(n=3$; Fig. $7 B, C)$.

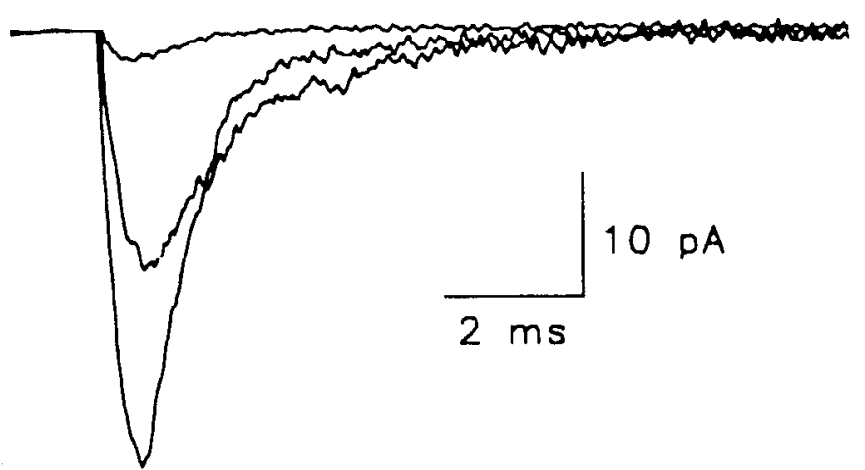

Figure 4. Effect of OAG on macroscopic sodium currents recorded in a cell-attached patch on an undifferentiated MMl4 cell. Voltage pulses to $-30 \mathrm{mV}$ were applied from a holding potential of $-130 \mathrm{mV}$. Currents were recorded in control and 0.5 and 30 min after bath application of $60 \mu \mathrm{M}$ OAG. Bath solution C, pipette solution D. 

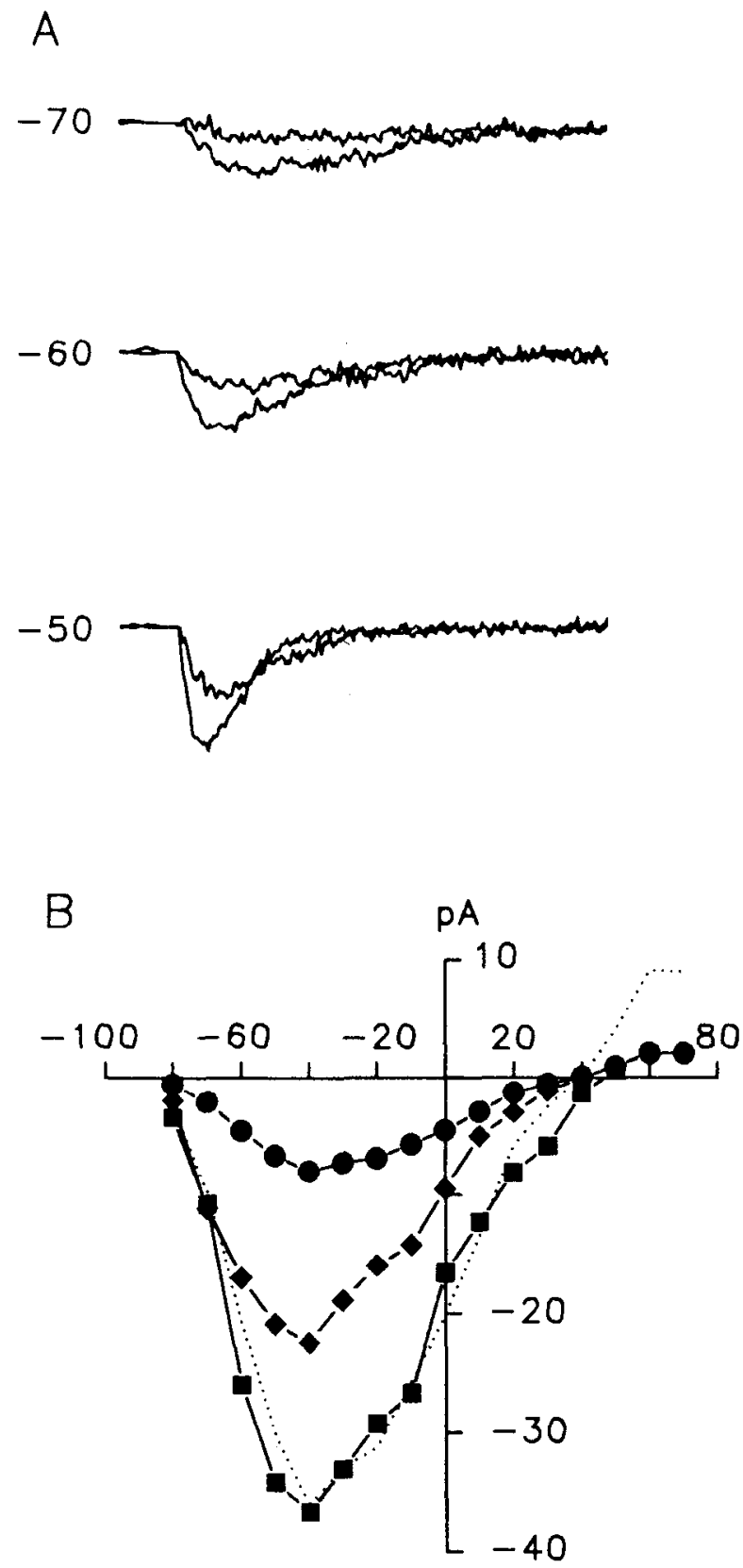
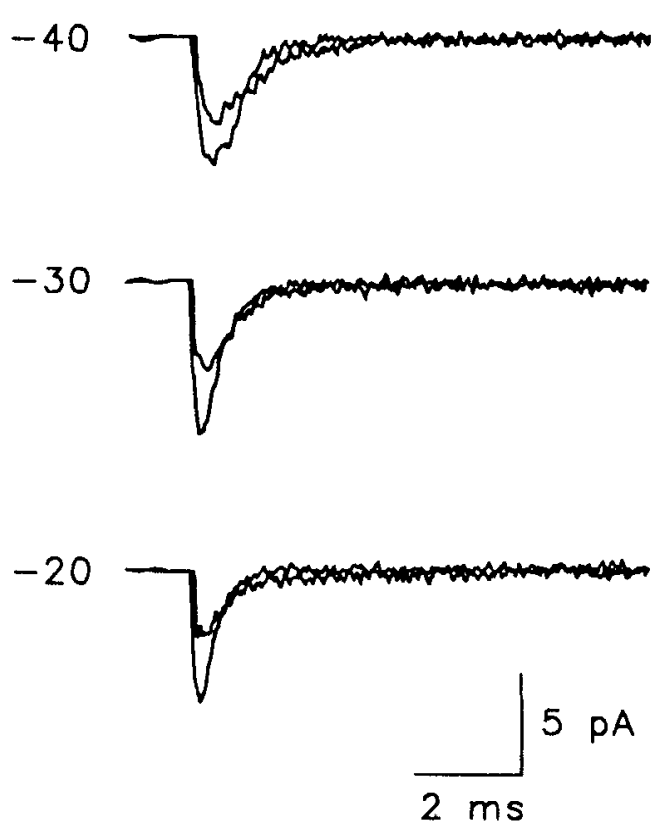

C

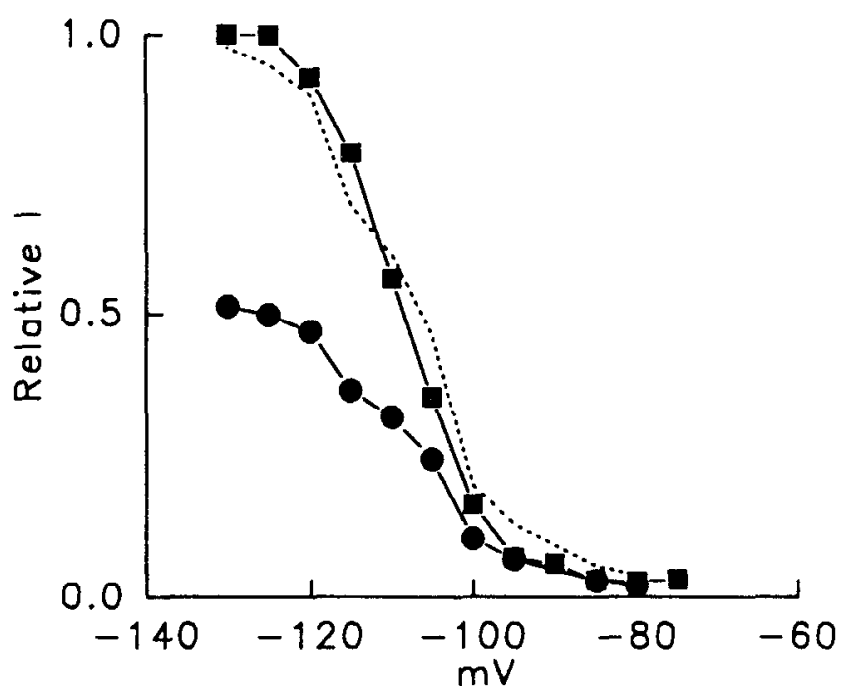

Figure 5. Effect of OAG on the voltage-dependent properties of macroscopic sodium currents in a cell-attached patch on an undifferentiated MM14 cell. A, Currents recorded before and after bath application of $20 \mu \mathrm{M}$ OAG during voltage steps to the indicatcd voltages from a holding

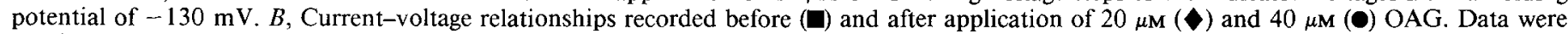
obtained after 20-25 min when the OAG effect had reached a steady state. Dashed line is a scaled version of the $40 \mu \mathrm{M}$ data. $C$, Inactivation curves measured in control and $22 \mathrm{~min}$ after $30 \mu \mathrm{M}$ OAG addition in a different cell; 125 -msec-long prepulses to various potentials were followed by test depolarizations to $0 \mathrm{mV}$. Dashed curve is a scaled version of the OAG data. Bath solution C, pipette solution D.

Modulation of skeletal muscle sodium channels in rat muscle cells by $P K C$

Rat skeletal muscle myoballs were used to examine effects of PKC activation on skeletal muscle sodium channels in a muscle cell background. These cells contain two sodium channel subtypes with different TTX sensitivities (Gonoi et al., 1985; Weiss and Horn, 1986). The first channel type, characteristic of adult skeletal muscle, is TTX sensitive $\left(K_{D}=5-10 \mathrm{nM}\right)$. The second type, characteristic of embryonic and denervated muscle, is resistant to both TTX $\left(K_{D}=2 \mathrm{mM}\right)$ and $\mu$-conotoxin (Gonoi et al., 1987). Whole-cell sodium currents recorded from our rat skeletal muscle myoball preparation were reduced $75 \pm 18 \%$ by $400 \mathrm{nM}$ TTX $(n=4)$ and almost completely eliminated by 5-10 $\mu \mathrm{M}$ TTX $(n=6)$, indicating that a large fraction of the channels are of the adult type.

Sodium currents recorded in cell-attached patches from skcletal muscle myoballs were slowed and reduced in size when exposed to $40-60 \mu \mathrm{M}$ OAG (Fig. 8). However, unlike the results in MM 14 cells, both effects were transient and returned to control levels within $8 \mathrm{~min}$. An additional application of $\mathrm{OAG}$ produced a second slowing and decrease of the current that was 
A

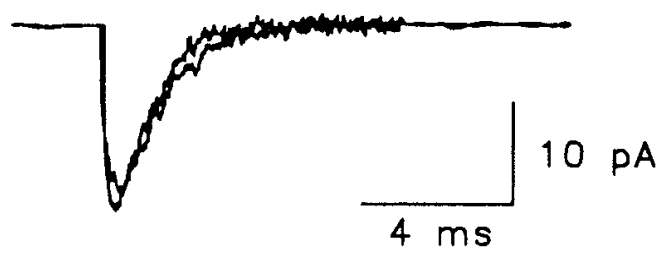

B

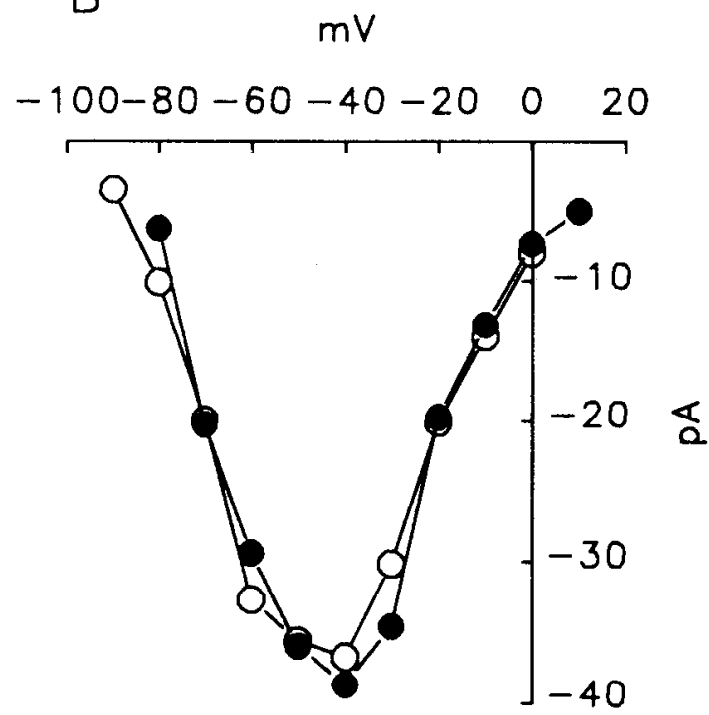

C

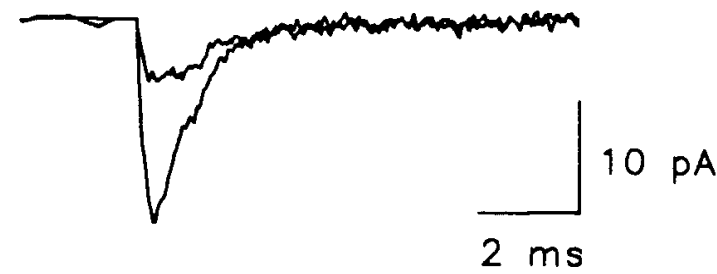

D

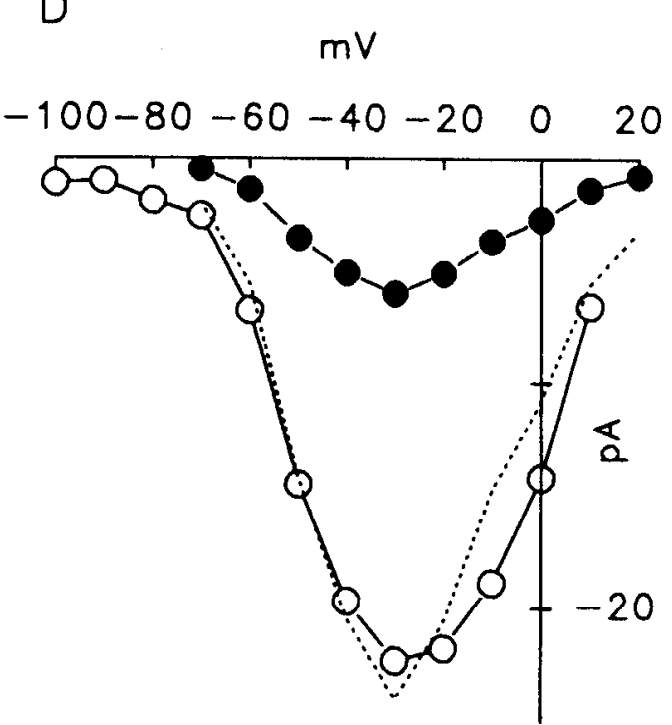

Figure 6. OAG effects on MM14 myoblast sodium currents are blocked by a specific inhibitor of PKC (PKCI) but not by a specific inhibitor of cAMP-dependent protein kinase (PKAI). A, Currents from a cell-attached patch elicited by voltage steps to $-30 \mathrm{mV}$ before and after exposure to $100 \mu \mathrm{M}$ OAG for $30 \mathrm{~min}$. This MM14 cell had been injected $8 \mathrm{~min}$ earlier with $500 \mu \mathrm{M}$ PKCI. $B$, Current-voltage relationship from another similarly preinjected cell before $(O)$ and after $(\bullet)$ exposure to $100 \mu \mathrm{M}$ OAG. $C$, Cell-attached currents elicited by voltage steps to $-20 \mathrm{mV}$ before and after application of $60 \mu \mathrm{M}$ OAG in a cell injected with a solution containing $1 \mathrm{mM}$ PKAI. $D$, Current-voltage relationship from the same cell before $(O)$ and after $(0) \mathrm{OAG}$. The dashed trace is a scaled version of the OAG data. Bath solution E, pipette solution D.

also transient. Although the effect was qualitatively similar to that seen in MM14 cells, its transient nature made it difficult to study. The rapid reversal of the effect of protein kinase activation by diacylglycerols in these cells might reflect rapid degradation of OAG, rapid dephosphorylation of the sodium channel, or both.

\section{Biphasic effect of $P K C$ activation}

The two effects of OAG stimulation in undifferentiated MM14 cells, slowing of macroscopic inactivation and reduction of peak sodium current, were separable on the basis of time after application of $O A G$ and concentration. After addition of $O A G$ at high concentration $(60 \mu \mathrm{M})$, these two changes occurred in a stereotyped pattern (Fig. 9A). Macroscopic inactivation began to slow immediately after OAG addition (trace a, $3 \mathrm{~min}$ ), but the peak sodium current was not reduced. At slightly longer times, peak sodium current was also reduced (trace b, $6 \mathrm{~min}$ ) and maximal slowing of the current decay is observed. However, peak sodium current continued to decrease without further slowing for up to $20 \mathrm{~min}$ (trace c) before reaching a steady state.

A similar biphasic effect is seen when the concentration of OAG is varied (Fig. $9 B$ ). At low OAG concentrations $(10 \mu \mathrm{M})$, macroscopic inactivation is slowed but there is little reduction of peak current. Reduction of peak current occurs at higher

\begin{tabular}{|c|c|c|c|c|}
\hline $\mathrm{OAG}(\mu \mathrm{M})$ & $\begin{array}{l}\text { Normalized } \\
\text { peak current }\end{array}$ & $\begin{array}{l}\text { Normalized } \\
\text { current integral }\end{array}$ & $\begin{array}{l}\text { Normalized } \\
\text { time constant }\end{array}$ & $n$ \\
\hline \multicolumn{5}{|c|}{ Undifferentiated cells } \\
\hline 0 & 1.0 & 1.0 & 1.0 & \\
\hline $1-10$ & $1.10 \pm(0.13)$ & $1.53 \pm(0.30)$ & $1.55 \pm(0.34)$ & 5 \\
\hline $20-40$ & $0.46 \pm(0.17)$ & $1.44 \pm(0.23)$ & $1.54 \pm(0.25)$ & 14 \\
\hline $40-75$ & $0.12 \pm(0.05)$ & $1.53 \pm(0.24)$ & $1.65 \pm(0.52)$ & 8 \\
\hline \multicolumn{5}{|c|}{ Differentiated cells } \\
\hline 0 & 1.0 & 1.0 & 1.0 & \\
\hline $1-10$ & 1.0 & 1.0 & 1.0 & \\
\hline $20-40$ & $0.76 \pm(0.31)$ & $1.41 \pm(0.20)$ & $1.36 \pm(0.23)$ & 3 \\
\hline $40-75$ & $0.67 \pm(0.26)$ & $1.50 \pm(0.26)$ & $1.49 \pm(0.33)$ & 9 \\
\hline $75-100$ & $0.42 \pm(0.14)$ & $1.52 \pm(0.25)$ & $1.72 \pm(0.34)$ & 6 \\
\hline
\end{tabular}

Data show stcady-statc effects of the indicated OAG concentrations on peak current and current time course in cell-attached patches from udifferentiated and differentiated MM14 cells. Relative peak current is the peak current after exposure to the indicated $O A G$ concentration divided by the control value observed before OAG treatment. Normalized integrated current is the integrated current during the pulse calculated after normalization of the peak current to the control level. It is roughly proportional to the rate of macroscopic inactivation, which determines the length of the current. Normalized time constant is the time constant after exposure to OAG divided by the control value observed before OAG treatment. The time constant was determined by fitting a monoexponential function to current decay after the peak. 
A

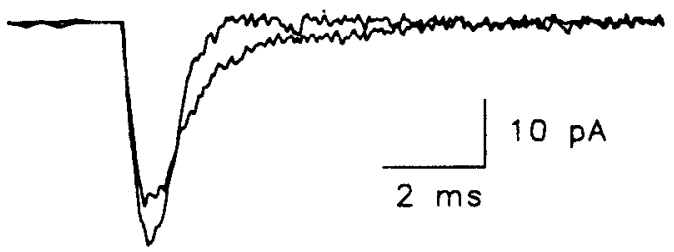

B

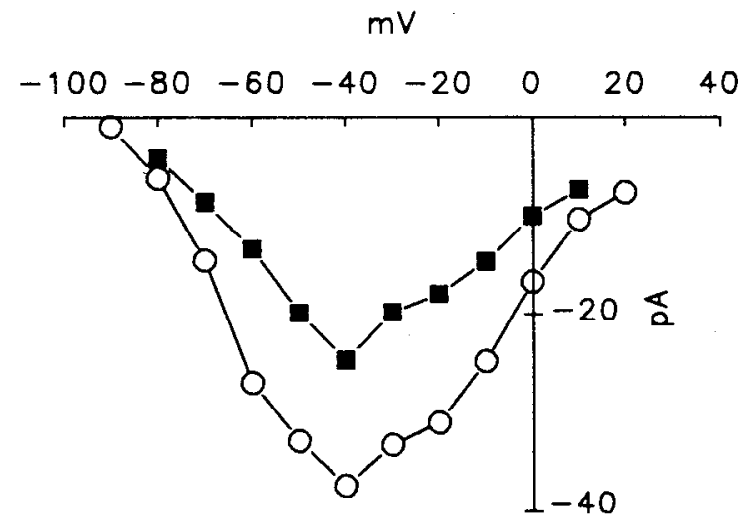

C

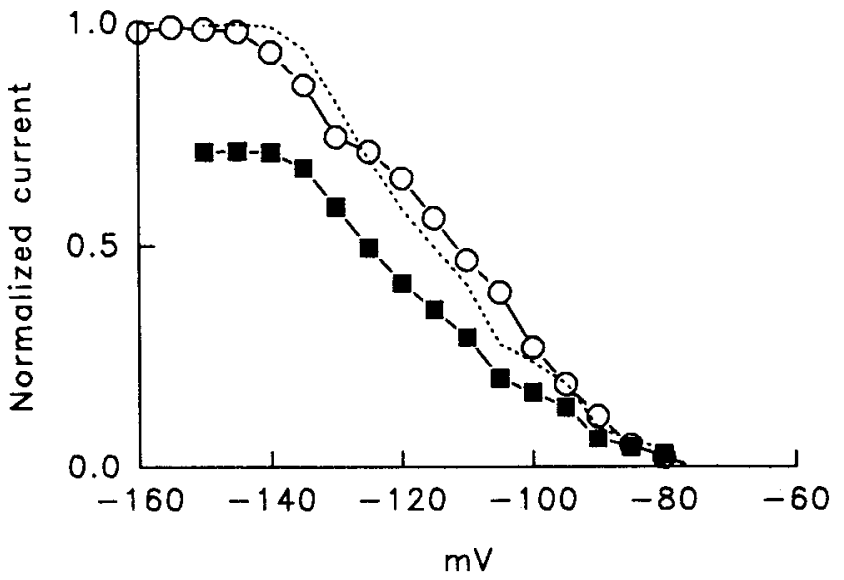

Figure 7. Modulation of sodium current by OAG in a differentiated MM14 cell $72 \mathrm{hr}$ after FGF withdrawal. $A$, Cell-attached currents in response to a voltage-step to $-20 \mathrm{mV}$ before and $10 \mathrm{sec}$ after addition of $60 \mu \mathrm{M}$ OAG to the bath. $B$ and $C$, Current-voltage relationship $(B)$ and inactivation curve $(C)$ before OAG addition $(O)$ and after the OAG effect on sodium current had reached a steady state (approximately 20 min; $)$. Dashed line is a scaled version of the OAG data. Bath solution $\mathrm{F}$, pipette solution $\mathrm{G}$.

concentrations with little additional slowing. Steady-state effects were quantified (Table 1) by measuring the time constant of macroscopic inactivation and the peak current as a function of concentration. Maximal effects on slowing occur at lower concentrations than maximal effects on peak current.

\section{Single-channel events underlying PKC effects on the sodium} current of MM14 cells

The behavior of single sodium channels underlying the effect of OAG is illustrated in Figure 10. In a control patch containing five to six channels, superimposed openings cluster at the be-

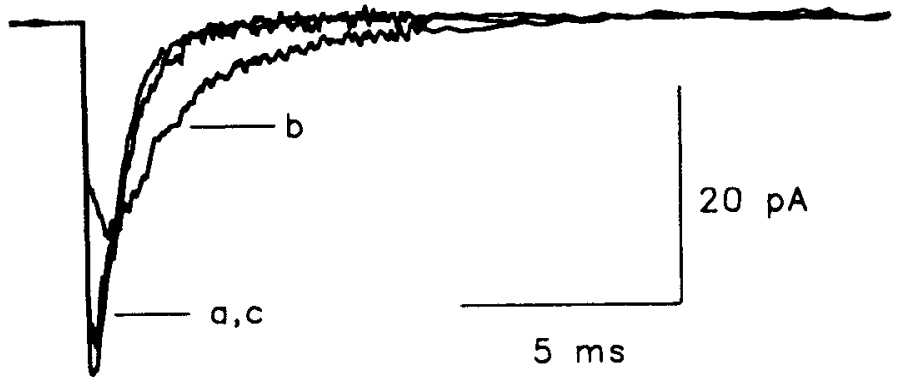

Figure 8. OAG effects on sodium current in a rat skeletal muscle myoball: current traces from a cell-attached patch before $(a)$ and $1 \mathrm{~min}$ (b) and $8 \mathrm{~min}(c)$ after addition of $60 \mu \mathrm{M}$ OAG. Bath solution $\mathrm{F}$, pipette solution $\mathrm{G}$.

ginning of depolarizations to $-30 \mathrm{mV}$. This reflects channel activation followed by rapid inactivation. Within $30 \mathrm{sec}$ of adding $30 \mu \mathrm{M}$ OAG to the bath, single channel openings occur throughout many of the pulses. Similar behavior was observed in both undifferentiated and differentiated MM14 cells. In five

A
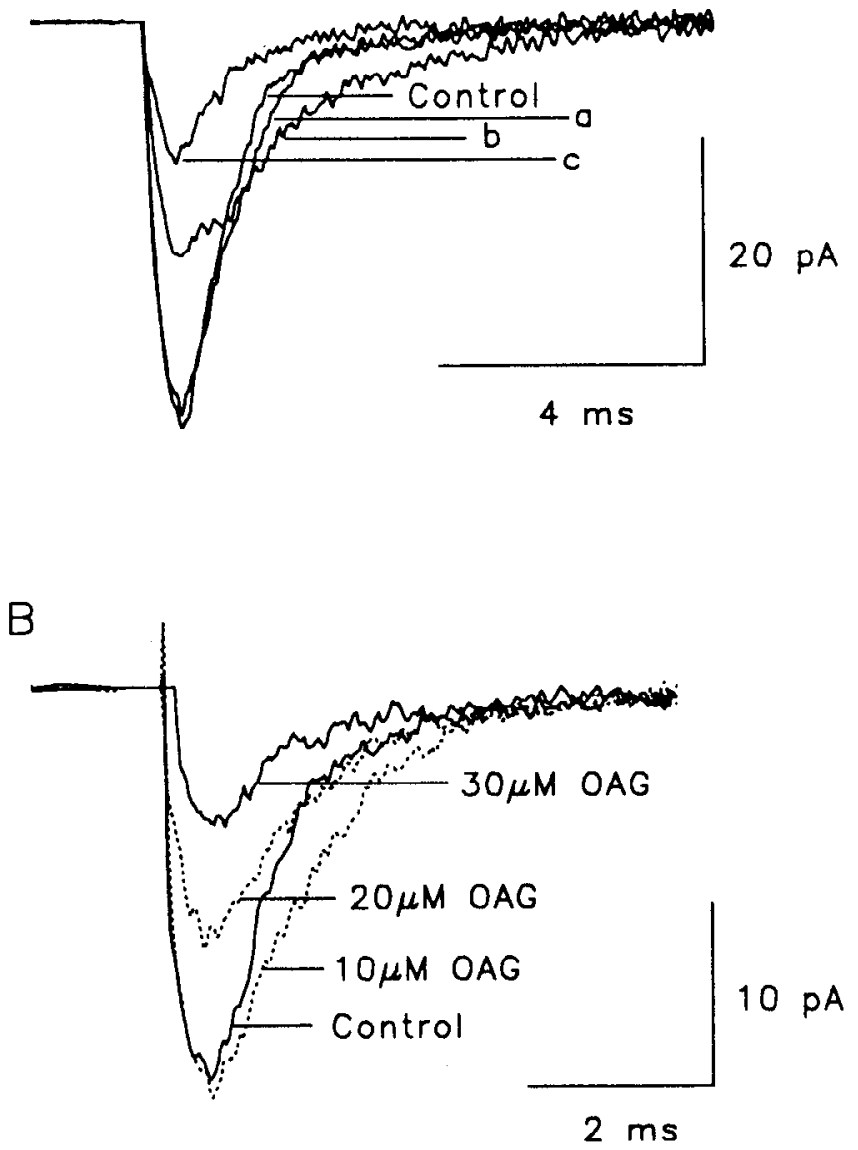

Figure 9. Time and dose dependence of $\mathrm{OAG}$ effects in undifferentialed MM 14 cells. $A$, Cell-attached recording from an MM14 cell before and during application of $60 \mu \mathrm{M}$ OAG. Current traces during voltage pulses to $-30 \mathrm{mV}$ in control and $3 \mathrm{~min}(a), 6 \mathrm{~min}(b)$, and $10 \min (c)$ after $O A G$ addition. Holding potential was $-130 \mathrm{mV} . B$, Current traces from a cell-attached patch in control and after perfusion of the indicated $\mathrm{OAG}$ concentrations during voltage steps to $-30 \mathrm{mV}$ from a holding potential of $-120 \mathrm{mV}$. Bath solution $\mathrm{C}$, pipette solution $\mathrm{D}$. 
A
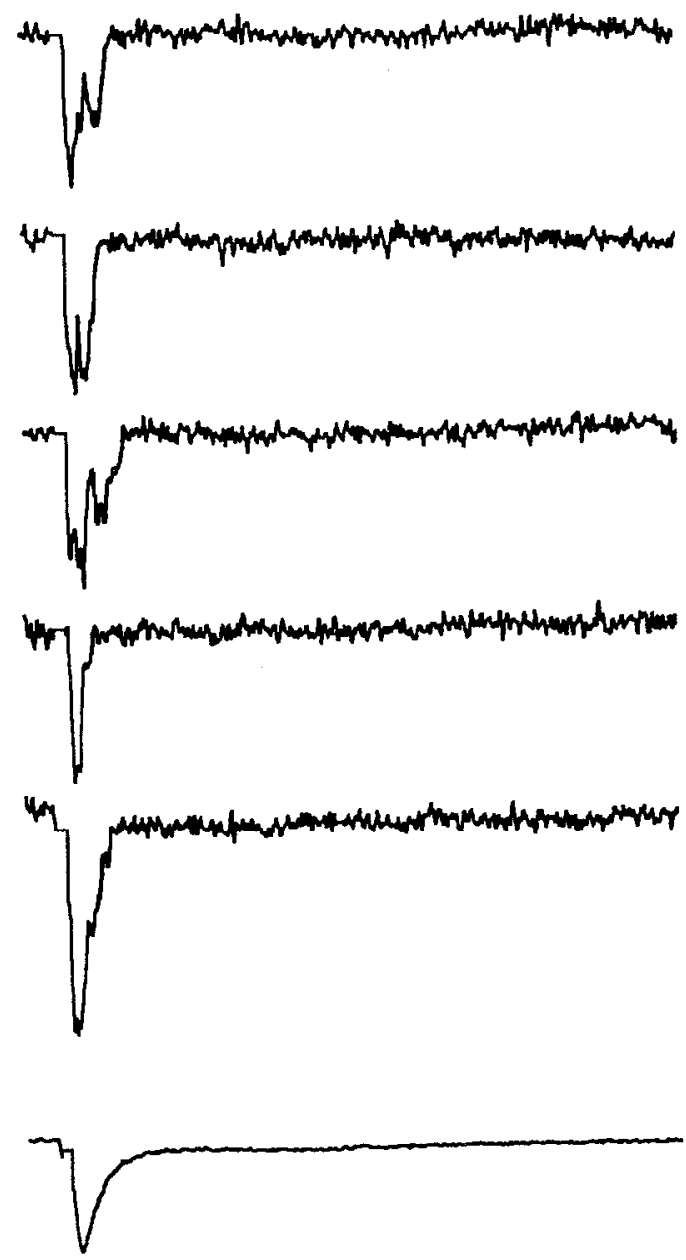

B

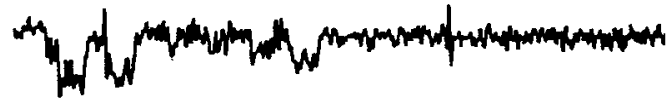

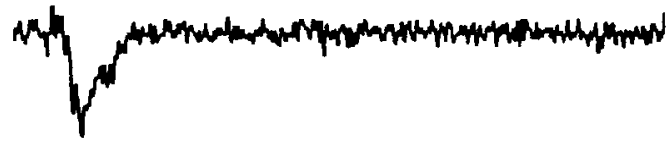

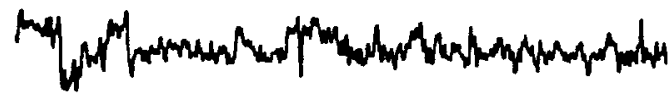

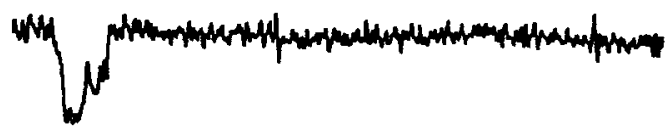
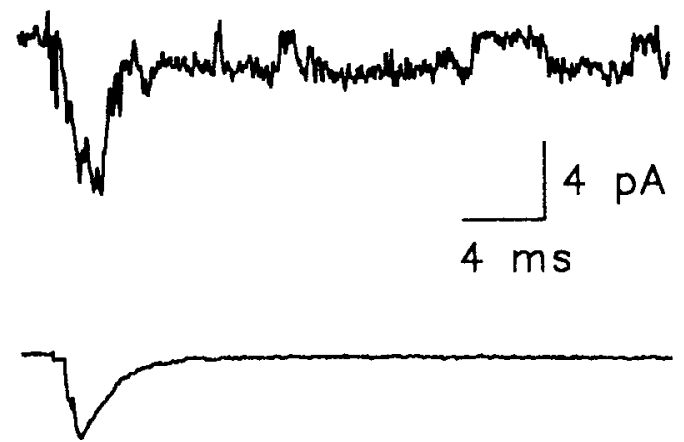

Figure 10. Effect of OAG on unitary differentiated MM1 4 cell sodium currents: cell-attached recording from a patch containing five to six sodium channels before $(A)$ and after $(B)$ addition of $30 \mu \mathrm{M}$ OAG. The last trace in each column is an ensemble average of the single-channel traces recorded in each condition. Test depolarizations to $-40 \mathrm{mV}$ applied at $0.2 \mathrm{~Hz}$. Holding potential was $-120 \mathrm{mV} ; 4 \mathrm{kHz}$ filter. Bath solution $\mathrm{C}$, pipette solution D.

other patches containing five to six channels each, late activity (defined as openings $>5 \mathrm{msec}$ long or occurring after $20 \mathrm{msec}$ of depolarization) was seen in $27.7 \%$ of the sweeps (954 sweeps at voltages ranging from -30 to $-60 \mathrm{mV}$ ). Such openings are observed in control recordings at much lower frequency $(1.3 \%$ of 1878 sweeps) in patches containing a similar number of channels. These results show that reopening of sodium channels during long depolarizations is dramatically increased by PKC. This reopening behavior in combination with the increased duration of activity early in the pulse leads to the slowed time course of ensemble-averaged currents seen after $O A G$ addition. A detailed study of OAG modulation of single sodium channels is in progress.

\section{Discussion}

Adult skeletal muscle sodium channels are expressed in a satellite cell line

The satellite cell-derived MM14 cells were particularly useful for our studies as they appear to express only the adult skeletal muscle sodium channel type corresponding to the $\mu 1$ sodium channel that has been characterized by cloning and sequencing
(Trimmer et al., 1989). Consistent with this conclusion, the sodium channel in MM14 cells has high sensitivity to both TTX and $\mu$-conotoxin. This pharmacological profile is unique for the $\mu 1$ sodium channel expressed in adult skeletal muscle among sodium channels that have been characterized. Other physiological properties of MM14 cell sodium currents were also characteristic of adult skeletal muscle sodium channels. Skeletal muscle sodium channels activate and inactivate at particularly negative membrane potentials. Literature values for mammalian skeletal muscle fiber half-activation range from -44 to -52 $\mathrm{mV}$ and for half-inactivation from -70 to $-92 \mathrm{mV}$ (Adrian and Marshall, 1977; Pappone, 1980; Mathes et al., 1991). Values obtained in whole-cell voltage-clamp studies of primary cultured rat skeletal muscle myoballs differ slightly, with half-activation and inactivation being $-31 \mathrm{mV}$ and $-74 \mathrm{mV}$, respectively, soon after breaking into the cell (Gonoi et al., 1985), but these values shift to more negative potentials over time, eventually approximating those observed in intact skeletal muscle. Whole-cell currents in undifferentiated MM14 cells behaved similarly to those in skeletal muscle myoballs. Soon after breaking the cell membrane, current-voltage curves had peaks near 
- $10 \mathrm{mV}$ that gradually shifted to $-30 \mathrm{mV}$ over the next $10-$ $20 \mathrm{~min}$. The reversal potential remained constant near +70 $\mathrm{mV}$. After shifting, half-activation and inactivation voltages were -45 and $-91 \mathrm{mV}$, respectively, values that are similar to the values for intact mammalian skeletal muscle fibers (Adrian and Marshall, 1977; Pappone, 1980; Mathes et al., 1991). Thus, the MM14 sodium channels present in both undifferentiated and differentiated MM14 cells can be identified as the adult skeletal muscle subtype.

The MM 14 cell line has becn extensively used to study muscle differentiation. Most muscle-specific proteins are expressed only after differentiation has been induced by FGF withdrawal. These include myosin heavy chains (Clegg et al., 1987), ACh receptors (Linkhart et al., 1980), $\alpha$-actin (Bulinski et al., 1983), and creatine kinase (Chamberlain et al., 1985; Jaynes et al., 1986). At the same time, EGF and FGF receptors are lost (Lim and Hauschka, 1984; Olwin et al., 1988; Templeton and Hauschka, 1992). Some ion channels including calcium channels and delayed rectifier potassium channels are expressed only after differentiation (R. Numann and T. Scheuer, unpublished observations). Similarly, in rat muscle, expression of adult sodium channels begins at roughly the time of myoblast fusion and increases from birth to $21 \mathrm{~d}$, a pattern that is maintained in primary cultured myoblasts (Sherman and Catterall, 1982, 1984; Gonoi et al., 1985, 1987). However, $\mu$-conotoxin-sensitive sodium channels are detected in both undifferentiated and differentiated MM14 cells. Thus, expression of muscle-specific sodium channels must be controlled differently than most other muscle-specific proteins in this satellite cell line.

Adult satellite cells attached to skeletal muscle in vivo express large sodium currents. While some of this current is TTX resistant (Bader et al., 1988), it is not known whether primary satellite cells also have adult channels. Thus, it is unclear whether the adult $\mathrm{Na}$ channels in MM14 satellite cells represent a normal adult satellite cell phenotype or a unique property of these cells. The appearance of ACh-activated channels in adult satellite cells appears to be induced, or derepressed, by cell culture since such channels were not detected in satellite cells attached to intact muscle fibers or in satellite cells cultured for only $24 \mathrm{hr}$, whereas they did appear by $48 \mathrm{hr}$ in vitro (Bader et al., 1988). The finding that cultured satellite cells express adult $\mathrm{Na}$ channels is in parallel with detection of adult muscle-specific AChE (Senni et al., 1987) and ACh-activated ion channels (Cossu et al., 1987) in satellite cell-derived cultures but not in cultures of embryonic myoblasts. These previous studies plus our detection of adult-type sodium channels in MM14 myoblasts may indicate that a selected subprogram of muscle-specific gene expression occurs within replicating satellite muscle cells prior to activation of the more classical terminal differentiation program. Analysis of the developmental regulation of this subprogram in satellite versus embryonic myoblasts may provide clues as to the cell lineage processes involved in satellite cell determination.

\section{Skeletal muscle sodium channels are modulated by $P K C$}

Our results provide direct evidence that skeletal muscle sodium channels are modulated by PKC. In both MM14 cells and embryonic rat myotubes, activation of cellular $\mathrm{PKC}$ with a diacylglycerol activator causes both slowing of macroscopic sodium current inactivation and reduction in sodium current magnitude. The effects we observed are certainly due to activation of PKC since they are blocked by the specific pseudo-substrate inhibitor of PKC (House and Kemp, 1987). Likewise, they were not due to the action of cAMP-dependent protein kinase since a specific peptide inhibitor (Cheng et al., 1986) of this kinase had no effect.

At the single-channel level, the effects of PKC include appearance of prolonged single channel openings and a large increase in the reopening probability of sodium channels during sustained depolarizations. These two effects are primarily responsible for the slowed sodium current decay and prolonged sodium channel activity observed in macroscopic current recordings. We did not observe shifts in the voltage dependence of activation or inactivation that might cause changes in singlechannel behavior or in macroscopic current time course when examined at a specific membrane potential. These results are similar to those obtained in a more extensive analysis of $\mathrm{PKC}$ modulation of sodium channels in rat brain neurons and type IIA sodium channels expressed in a mammalian cell line ( $\mathrm{Nu}-$ mann et al., 1991, 1992b). This contrasts with studies of sodium channels expressed in Xenopus oocytes where the reduction in rat brain type IIA sodium current has been attributed to shifts in steady-state activation and slowing of sodium current has been attributed to effects on first latency of channel opening (Dascal and Lotan, 1990; Schreibmayer et al., 1991).

Interpretation of results in rat skeletal muscle myoballs is more complicated than in MM14 cells because they also express TTX-and $\mu$-conotoxin-resistant sodium channels (Gonoi et al., 1985, 1987; Weiss and Horn, 1986) characteristic of cardiac muscle and embryonic and denervated skeletal muscle. As in MM 14 cells, myoball sodium currents responded to OAG with a slowing of inactivation and a reduction in peak current, but it is not clear how much of the effect can be attributed to each channel subtype. In addition, the effect was transient, lasting only 4-5 min. This suggests a fast reversal of PKC activation, either because OAG is rapidly degraded in these cells (Asaoka et al., 1991) and/or because these cells have a high level of phosphatase activity that reverses the PKC-mediated phosphorylation.

Patlak and Ortiz (1986) have reported that single sodium channels in cell-attached patch recordings from adult frog skeletal muscle occasionally become noninactivating. These events were observed as maintained single-channel activity during a test pulse but were rare, occurring in less than $0.5 \%$ of the depolarizations for a patch containing six Na channels. Similar activity is observed for $\mu 1$ sodium channels expressed in mammalian cells (Ukomadu et al., 1992) and in Xenopus oocytes (Zhou et al., 1991). We observed similar activity in control cellattached patch recordings from MM14 cells. As in frog muscle and expressed $\mu 1$ channels, the sustained sodium channel activity is rare, occurring in only $1.3 \%$ of depolarizations for patches containing five or six channels. Interestingly, after application of OAG the percentage of sweeps having repetitive late openings increased dramatically to $27.7 \%$ of pulses for patches containing five or six channels. We speculate that the rare noninactivating events seen in frog skeletal muscle, $\mu 1$ sodium channels expressed transiently in mammalian cells, and in our control MM14 cell recordings were produced by transient phosphorylation of the sodium channel by basal activity of PKC or some other kinase. The noninactivating channel activity seen in both frog muscle and MM14 cells in the absence of PKC stimulation is qualitatively similar to the enhanced activity seen after treatment with OAG, but we have not yet made a detailed, quantitative comparison. 
Sodium channel modulation by PKC is biphasic and likely involves two phosphorylation sites

We found that the two effects of OAG on sodium channels can occur separately in MM14 cells. At the lowest concentrations of OAG studied, slowing of the sodium current can be observed in the absence of peak current reduction. Intermediate $O A G$ concentrations caused the sodium current to initially become slow with no decrease or even an increase in peak current amplitudc. This slowing was complete within 2-3 min and was then followed by a reduction in peak current that continued for up to $30 \mathrm{~min}$. These two effects are biphasic in their impact on cellular excitability. Slowing of macroscopic sodium current inactivation prolongs the sodium current and is an activating influence at the cellular level; reduction of peak sodium currents is an inhibiting influence on electrical excitability at the cellular level.

Given their differential sensitivity to OAG, it seems likely that at least two separate phosphorylation sites are required for the two effects of modulation of skeletal muscle sodium channels by PKC. Although there are multiple consensus sequences for PKC phosphorylation in the $\mu 1$ sodium channel (Trimmer et al., 1989), one phosphorylation site is likely to be the highly conserved serine at the position equivalent to 1506 in the rat brain type IIA sodium channel (Ser1321 in the $\mu 1$ muscle channel; Trimmer et al., 1989). Phosphorylation of this site is required for both PKC effects on the rat brain sodium channels (West et al., 1991). This site is in the center of the highly conserved intracellular loop between homologous domains III and IV of the sodium channel, and the site itself is conserved in all sodium channel $\alpha$ subunits that have been functionally expressed. This short intracellular loop is important in mediating sodium channel fast inactivation and may serve as the inactivation gate itself (Stühmer et al., 1988; Vassilev et al., 1988, 1989; Patton et al., 1992; West et al., 1992). A conserved phenylalanine at position 1489 in the rat brain type IIA channel is required for that process (West et al., 1992). For type IIA sodium channels, it appears that Ser 1506 alone is responsible for slowing inactivation, but is not sufficient for reduction of peak sodium current. Mutation of another serine residue in the large intracellular loop between homologous domains I and II $\left(\mathrm{L}_{1 / 11}\right)$ of the type IIA sodium channel blocks sodium current reduction by OAG but slowing occurs normally (Numann et al., 1992b). Most of $\mathrm{L}_{1 / 11}$ is absent from the $\mu 1$ sodium channel sequence (Trimmer et al., 1989), and the critical serine residue is not conserved. We suggest that, in skeletal muscle sodium channels lacking phosphorylation sites in $\mathrm{L}_{1 / 1 \mathrm{I}}$, phosphorylation at Ser 1506 causes slowing of inactivation directly and allows reduction of sodium current by phosphorylation at another unidentified PKC site in analogy with our results on type IIA sodium channels. Additional mutagenesis studies on both neuronal and muscle sodium channels are necessary to clarify the complex interactions between multiple sites of PKC phosphorylation.

\section{Possible physiological effects of PKC modulation}

Regardless of the exact mechanism of action of phosphorylation, the modulation of skeletal muscle channels by PKC has profound physiological implications. At low levels of PKC stimulation, macroscopic inactivation of skeletal muscle sodium current would be slowed by as much as twofold with little reduction in size. This would be expected to prolong action potentials and increase muscle fiber excitability. Since PKC activity is regulated by cylusolic calcium concentration as well as by diacylglycerol levels, muscle action potentials may be subject to dynamic modulation dependent on the level of muscle activity and its consequent effects on cytosolic calcium. Higher levels of PKC activation would dramatically decrease the sodium current and protect the muscle fiber from over stimulation.

The acute physiological effects of PKC stimulation on overall muscle fiber electrical activity are not completely defined. Activation of $\mathrm{PKC}$ causes repetitive firing in mouse skeletal muscle (Brinkmeier and Jokusch, 1987). PKC activation has been associated with increased $\mathrm{ACh}$ receptor activity (Caratsch et al., 1989) and reduced resting chloride channel activity (Brinkmeier and Jokusch, 1987; Bryant and Conte-Camerino, 1991) in addition to the effects on sodium channels described here. The effects of PKC activation on ACh receptors, chloride channels, and sodium channels all could contribute to enhanced excitability and may be responsible for the repetitive firing observed in mouse skeletal muscle.

\section{References}

Adrian RH, Marshall MW (1977) Sodium currents in mammalian muscle. J Physiol (Lond) 268:223-250.

Asaoka Y, Oka M, Yoshida K, Nishizuka Y (1991) Metabolic rate of membrane-permeant diacylglycerol and its relation to human resting T-lymphocyte activation. Proc Natl Acad Sci USA 88:8681-8685.

Bader CR, Bertrand D, Cooper E, Mauro A (1988) Membrane currents of rat satellite cells attached to intact skeletal muscle fibers. Neuron $1: 237-240$

Baer M, Best PM, Reuter H (1976) Voltage-dependent action of tetrodotoxin of mammalian cardiac muscle. Nature 263:344-345.

Barchi RL (1988) Probing the molecular structure of the voltagedependent sodium channel. Annu Rev Neurosci 1 1:485-495.

Brinkmeier H, Jockusch H (1987) Activators of protein kinase C induce myotonia by lowering chloride conductance in muscle. Biochem Biophys Res Commun 148:1383-1389.

Bryant SH, Conte-Camerino D (1991) Chloride conductance regulation in the skeletal muscle of normal and myotonic goats. Pfluegers Arch 417:605-610.

Bulinski JC, Kumar S, Titani K, Hauschka SD (1983) Peptide antibody specific for amino terminus of skeletal muscle-actin. Proc Natl Acad Sci USA 80:1506-1510.

Caratsch CG, Knoflach F, Grassi F, Eusebi F (1989) Regulation of acetylcholine receptor function by the phorbol ester TPA in rat skeletal muscle. Naunyn Schmiedebergs Arch Pharmacol 340:82-86.

Chamberlain JS, Jaynes JB, Hauschka SD (1985) Regulation of creatine kinase induction in differentiating mouse myoblasts. Mol Cell Biol 5:484-492.

Cheng H-C, Kemp BE, Pearson RB, Smith AJ, Misconi L, Patten VMS, Walsh DA (1986) A potent synthetic peptide inhibitor of the CAMPdependent protein kinase. J Biol Chem 261:989-992.

Clegg CH, Linkhart TA, Olwin BB, Hauschka SD (1987) Growth factor control of skeletal muscle differentiation occurs in $G_{1}$ phase and is repressed by fibroblast growth factor. J Cell Biol 105:949-956.

Cohen CJ, Bean BP, Colatsky TJ, Tsien RW (1981) Tetrodotoxin block of Na channels in rabbit Purkinje fibers. J Gen Physiol 78:383411.

Cossu G, Eusebi F, Grassi F, Wanke E (1987) Acetylcholine receptor channels are present in undifferentiated satellite cells but not in embryonic myoblasts in culture. Dev Biol 123:43-50.

Cruz LJ, Gray WR, Olivera BM, Zeikus RD, Kerr L, Yoshikami D, Moczydlowski.E (1985) Conus geographus toxins that discriminate between neuronal and muscle sodium channels. J Biol Chem 260: 9280-9288.

Dascal N, Lotan I (1991) Activation of protein kinase C alters voltage dependence of $\mathrm{Na}^{+}$channel. Neuron 6:165-175.

Gonoi T, Sherman SJ, Catterall WA (1985) Voltage clamp analysis of tetrodotoxin-sensitive and -insensitive sodium channels in rat muscle cells developing in vitro. J Neurosci 5:2559-2564.

Gonoi T, Ohizumi Y, Nakamura H, Kobayashi J, Catterall WA (1987) The Conus toxin geographutoxin II distinguishes two functional so- 
dium channel subtypes in rat muscle cells developing in vitro. J Neurosci 7:1728-1731.

Hamill OP, Marty A, Neher E; Sakmann B, Sigworth FJ (1981) Improved patch-clamp techniques for high-resolution current recording from cells and cell-free membrane patches. Pfluegers Arch 391:85100.

House C, Kemp BE (1987) Protein kinase C contains a pseudosubstrate prototype in its regulatory subunit. Science 238:1726-1728.

Jaynes JB, Chamberlain JS, Buskin JN, Johnson JE, Hauschka SD (1986) Transcriptional regulation of the muscle creatine kinase gene and regulated expression in transfected mouse myoblasts. Mol Cell Biol 6:2855-2864.

Lawrence JC, Catterall WA (1981) Tetrodotoxin-insensitive sodium channels. Binding of polypeptide neurotoxins in primary cultures of rat muscle cells. J Biol Chem 256:6223-6229.

Lim RW, Hauschka SD (1984) A rapid decrease in epidermal growth factor-binding capacity accompanies the terminal differentiation of mouse myoblasts in vitro. J Cell Biol 98:739-747.

Linden DJ, Routtenberg A (1989) Cis-fatty acids, which activate protein kinase $\mathrm{C}$, attenuate $\mathrm{Na}^{+}$and $\mathrm{Ca}^{2+}$ currents in mouse neuroblastoma cells. J Physiol (Lond) 419:95-119.

Linkhart TA, Clegg CH, Hauschka SD (1980) Control of mouse myoblast commitment to terminal differentiation by mitogens. J Supramol Struct 14:483-498.

Linkhart TA, Clegg C, Hauschka SD (1981) Myogenic differentiation in permanent clonal mouse myoblast ccll lines: rcgulation by macromolecular growth factors in culture medium. Dev Biol 86:19-30.

Mathes C, Bezanilla F, Weiss RE (1991) Sodium current and membrane potential in EDL muscle fibers from normal and dystrophic $(m d x)$ mice. Am J Physiol 261:C718-C725.

Minoshima S, Kobayashi M, Nakamura H, Kobayashi J, Ogura A, Takahashi M, Ohizumi Y (1984) Pharmacological effects of geographutoxin II isolated from the venom of Conus geographus on skeletal muscles. Jpn J Pharmacol 36:192.

Numann R, Catterall WA, Scheuer T (1991) Functional modulation of brain sodium channels by protein kinase $C$ phosphorylation. Science 254:115-118.

Numann R, Hauschka SD, Scheuer T, Catterall WA (1992a) Modulation of skeletal muscle $\mathrm{Na}$ channel by protein kinase $\mathrm{C}$. Biophys $\mathrm{J}$ 61:A112.

Numann R, West JW, Li M, Smith RD, Goldin AL, Scheuer T, Catterall WA (1992b) Biphasic modulation of sodium channels by phosphorylation at two different sites. Soc Neurosci Abstr 18:1133.

Olwin BB, Hauschka SD (1988) Cell surface fibroblast growth factor and epidermal growth factor receptors are permanently lost during skeletal muscle terminal differentiation in culture. J Cell Biol 107: 761-769.

Pappone PA (1980) Voltage clamp experiments in normal and denervated mammalian skeletal muscle fibres. J Physiol (Lond) 306 : $377-410$.

Patlak JB, Ortiz M (1986) Two modes of gating during late $\mathrm{Na}^{+}$ channel currents in frog sartorius muscle. J Gen Physiol 87:305-326.

Patton DE, West JW, Catterall WA, Goldin AL (1992) Amino acid residucs rcquircd for fast $\mathrm{Na}^{+}$-channcl inactivation: charge neutralizations and deletions in the III-IV linker. Proc Natl Acad Sci USA 89:10905-10909.
Ritchie JM, Rogart R (1977) The binding of saxitoxin and tetrodotoxin to excitable tissue. Rev Physiol Biochem Pharmacol 79:2-50.

Schreibmayer W, Dascal N, Lotan I, Wallner M, Weigl L (1991) Molecular mechanism of protein kinase $C$ modulation of sodium channel alpha-subunits expressed in Xenopus oocytes. FEBS Lett 291:341344.

Sculptoreanu A, Morton M, Gartside CL, Hauschka SD, Catterall WA, Scheuer T (1992) Tetrodotoxin-insensitive sodium channels in a cardiac cell line from a transgenic mouse. Am J Physiol 262:C724C730.

Senni MI, Castignanò F, Poiana G, Cossu G, Scarsella G, Biagioni S (1987) Expression of adult fast pattcrn of acetylcholinesterase molecular forms by mouse satellite cells in culture. Differentiation 36 : 194-198.

Sherman SJ, Catterall WA (1982) Biphasic regulation of development of the high-affinity saxitoxin receptor by innervation in rat skeletal muscle. J Gen Physiol 80:753-768.

Sherman SJ, Catterall WA (1984) Electrical activity and cytosolic calcium regulate levels of tetrodotoxin-sensitive sodium channels in rat muscle cells. Proc Natl Acad Sci USA 81:262-266.

Sigel E, Baur R (1988) Activation of protein kinase C differentially modulates neuronal $\mathrm{Na}^{+}, \mathrm{Ca}^{++}$and gamma-aminobutyrate type $\mathrm{A}$ channels. Proc Natl Acad Sci USA 85:6192-6196.

Stühmer W, Conti F, Suzuki H, Wang X, Noda M, Yahagi N, Kubo $\mathrm{H}$, Numa $\mathrm{S}$ (1988) Structural parts involved in activation and inactivation of the sodium channel. Nature 339:597-603.

Templeton TJ, Hauschka SD (1992) FGF-mediated aspects of skeletal muscle growth and differentiation are controlled by a high affinity receptor, FGFR1. Dev Biol 154:169-181.

Trimmer JS, Cooperman SS, Tomiko SA, Zhou J, Crean SM, Boyle MB, Kallen RG, Sheng Z, Barchi RL, Sigworth FJ, Goodman RH, Agnew WS, Mandel G (1989) Primary structure and functional expression of a mammalian skeletal muscle sodium channel. Neuron 3:33-94.

Ukomadu C, Zhou J, Sigworth FJ, Agnew WS (1992) $\mu 1 \mathrm{Na}^{+}$channels expressed transiently in human embryonic kidney cells: biochemical and biophysical properties. Neuron 88:663-676.

Vassilev PM, Scheuer T, Catterall WA (1988) Identification of an intracellular peptide segment involved in sodium channel inactivation. Scicnce 241:1658-1661.

Vassilev PM, Scheuer T, Catterall WA (1989) Inhibition of inactivation of single sodium channels by a site-directed antibody. Proc Natl Acad Sci USA 86:8147-8151.

Weiss RE, Horn R (1986) Functional differences between two classes of sodium channels in developing rat skeletal muscle. Science 233: 361-364.

West JW, Numann R, Murphy BJ, Scheuer T, Catterall WA (1991) A phosphorylation site in the $\mathrm{Na}^{+}$channel required for modulation by protein kinase C. Science 254:866-868.

West JW, Patton DE, Scheuer T, Wang Y, Goldin AL, Catterall WA (1992) A cluster of hydrophobic amino acid residues required for fast $\mathrm{Na}^{+}$channel inactivation. Proc Natl Acad Sci USA 89:1091010914.

Zhou J, Potts JF, Trimmer JS, Agnew WS, Sigworth FJ (1991) Multiple gating modes and the effect of modulating factors on the $\mu 1$ sodium channel. Neuron 7:775-785. 